\title{
Smart Library and Smart Campus
}

\author{
Hubert C. Y. Chan' ${ }^{1}$, Linus Chan ${ }^{2}$ \\ ${ }^{1}$ The Hong Kong Polytechnic University, Hong Kong, China \\ ${ }^{2}$ University of Montana, Missoula, USA \\ Email: hubertchan@hkc.net, linusylchan@gmail.com
}

How to cite this paper: Chan, H.C.Y. and Chan, L. (2018) Smart Library and Smart Campus. Journal of Service Science and Management, 11, 543-564.

https://doi.org/10.4236/jssm.2018.116037

Received: October 31, 2018

Accepted: November 25, 2018

Published: November 28, 2018

Copyright $\odot 2018$ by authors and Scientific Research Publishing Inc. This work is licensed under the Creative Commons Attribution International License (CC BY 4.0).

http://creativecommons.org/licenses/by/4.0/

\section{c) (i) Open Access}

\begin{abstract}
The consequence of digitalization, Internet proliferation, and technology advancement, our way of teaching and learning has been changing. The role of library has to be converted into a place for discourse, peer collaboration, social learning, and exhibition concourse. Some scholars believed that the future Library is tied to the technological development of Web4.0 which is characterized by the terminology of Convergence, Remixability, Standardization, Participation, Usability, Economy, and Design. This concept has been extended to Campus. Some universities have started to adopt the latest technology to convert their Campus and Library into Smart ones for the interests of students. The findings of this paper support that the latest development of Smart Campus and library aligns with the new trend of education system, and creates positive impact on the competitiveness of a city. The applications in Smart Camus and Library in reality are also revealed.
\end{abstract}

\section{Keywords}

Smart Library, Smart Campus, Connectivism, Education System, Competitiveness

\section{Introduction}

In the digital age, information can be disseminated through a variety of media besides hardcopy books or journals. The traditional role of library which is considered as an institution of information supply with a specific information structure that operates as an intermediary between supply and demand on diverse (information) markets (Hanekop and Wittke, 2006) [1] has been changing from passive mode as Web1.0 to active mode as Web2.0 onward. The changing natures of library will not only reflect that of the web but will also feature new attributes based on the uniqueness of libraries (Noh, Y., 2015) [2]. The characteristics of Web2.0 are rich user experience, user participation, dynamic content, 
metadata, scalability, openness, freedom and collective intelligence by way of user participation (Best, 2006) [3] while Library2.0 is defined as a subset of library services designed to meet user needs precipitated by the direct and peripheral effects of Web2.0 (Habib, 2006) [4]. Web2.0 was further developed into Web3.0. It combines the semantic web, Web2.0 applications and artificial intelligence, creates the opportunities and possibilities for the use of semantic tagging and annotation for the social web. This social semantic characteristic has been emphasized in library 3.0 (Alotaibi, 2010) [5]. Web3.0 is being evolved to Web4.0. Web4.0 is defined as an intelligent electronic agent, symbiotic, ubiquitous, and a machine which will be developed up to the level of human brain with advanced nanotechnology and human interaction interfaces (Patel K, 2013) [6]. We are already living in the era of Library 3.0, and Noh, Y (2015) [2] suggested a Library 4.0 model based on the development of Web4.0. He posited that Library 4.0 must include not only software-based approaches but also technological environment development such as maker space, Google Glass, context aware technology, digitalization of contents, big data, Cloud computing, and augmented reality. This concept has been extended to the whole Campus. Educationists believe that this Smart evolution can strengthen the learning capacity and capability of students. As we are moving toward this trend, would it align with that of the desirable education system development? The purpose of this paper is to examine the alignment of these two trends, and reveal the current technologies which are already deployed in the market.

\section{Education System}

South Korea, Japan, Hong Kong and Singapore, and Finland are considered to dominate the conversation of good education system

(https://www.linkedin.com/pulse/education-systems-around-world-comparison -sashi-gundala) [7]:

South Korea: South Korea spends $8 \%$ of its GDP on education as compared to a $6 \%$ average of other OECD participating countries. The main focus of their system is primary education. They make a good start with students, which carry them through the rest of their educational life. The students are known to go to school seven days a week. Parents are very involved and are willing to spend a lot of money to get their child the education they need. Teachers have to be highly qualified and are also highly paid. It is one of the coveted career choices in South Korea.

Japan/Singapore/Hong Kong: All three systems have a technology-based education structure. Science, Technology, Engineering, and Math (STEM) have been proliferating in primary education. They are also similar to South Korea in the fact that their main focus is also primary education and they spend a good percentage of their GDP on education. The primary, secondary and higher education levels are exemplary in their approach and work. Student retention is a common practice. The education system has moved instruction further away from the rote memorization and repetitive tasks on which it had originally fo- 
cused to deeper conceptual understanding and problem-based learning. The Singapore's ministry of education's recent policy of "Teach less, learn more" is highly popular and has catapulted its education system onto the top rungs in the world. The trend is adding Art into the STEM, and advocating the concept of STEAM.

Finland: School does not begin for children until they are 7 years old. There is no homework and no standardized testing until they reach high school. They have shorter school days. All schools follow a national curriculum. Students and teachers spend less time in schools in comparison to their American counterparts. Finland also provides three years of maternity leave, subsidized daycare and pre-school for 5 - 7 year olds where the emphasis is on playing and socializing.

Canada: They focus on three main parts: literacy, math and high school graduation. With a clear vision, they have created a transparent system in collaboration with administrators, teachers and the union to create a curriculum and methodology that is successful. The system encourages teamwork, quality education, continued teacher training, transparent results and a culture of sharing best practices. The teacher morale is also high because their pay is acceptable, working conditions are favorable, facilities are good and there are all kinds of opportunities for teachers to improve their practice. Most importantly, perhaps, there is discretion for teachers to make their own judgments.

The share of national universities in the top-200 of Hong Kong, Singapore, Canada, Finland, South Korea, and Japan are 18.2\%, 4.5\%, 4.3\%, 2.3\%, 0.8\% and $0.3 \%$ respectively while their Global Competitive Index

(https://www.weforum.org/agenda/2017/09/what-is-economic-competitiveness/) [8] are all above 5 as shown in Chart 1 below. It shows the current status but its policy, ultimate resource (teachers), openness and freedom must be aligned with the future needs [9] if they want to keep and improve their future competitiveness. The overall results of worldwide educating for the future index [9] has been listed for comparison. High Education and training is one of the 12 pillars of Competitiveness. This pillar measures secondary and tertiary enrollment rates as well as the quality of education as evaluated by business leaders. However, the Happy Planet Index is the other way round with the exception of Finland. It seems that no homework and no standardized testing in primary school do enhance Happiness. Competiveness and happiness can co-exist if our Education system is properly designed. In fact, Educational curricula cannot be remain unchanged, a career paths change faster, and are less linear than ever before according to the World Economic Forum's 2017 white paper [10] "Realizing Human Potential in the Forth Industrial Revolution". There is a consensus that no single skill set or area of expertise is able to sustain a long term career in the economics of the future. Educational institutions need to provide both in-depth subject knowledge as well as inter-disciplinary connections. The Future core skills of the $21^{\text {st }}$ century are complex problem solving, critical thinking, creativity, collaboration, and digital literacy. Globalization with greater integration 


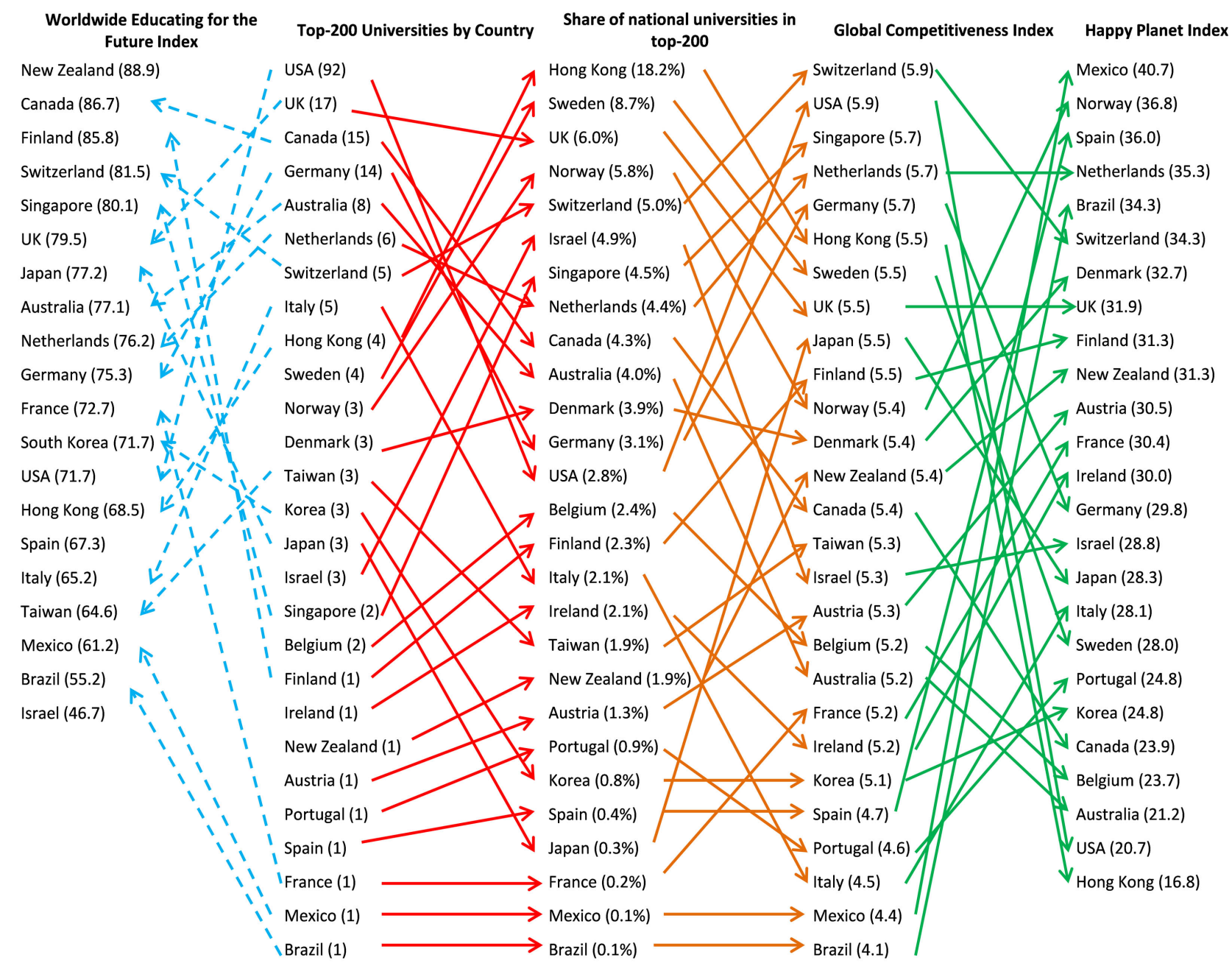

Chart 1. Comparison of top-200 universities, global competitiveness index, happy plant index and the worldwide educating for the future index. (Sources: The Worldwide Educating for the Future Index (2018), https://yidanprize.org/research/ [9];

https://www.weforum.org/agenda/2017/05/which-countries-provide-their-citizens-with-the-best-higher-education [22]; World Economic Forum, The Global Competitiveness Report 2017-2018 [23]; http://happyplanetindex.org/ [24]).

between economies across the globe and digital technology is driving younger generation to face a significantly different future world. They have to be equipped themselves new style of skill, namely Interdisciplinary skills, Creative and analytical skills, Entrepreneurial skills, Leadership skills, Digital and technical skills, and Global awareness and civic education [9]. These skills are ideally developed in early stage and then refined at colleges and universities, and lifelong learning. The curricula must be updated and adapted on a regular basic across industries according to the shifting demand in the labor market (https://toplink.weforum.org/knowledge/insight/a1Gb0000000LPFfEAO/explore/ summary) [11]. This is the principle of Connectivism which is considered to be the learning theory of the digital age, "a successor to behaviorism, cognitivism, and constructivism". It is an integration of the principles explored by chaos, network, and complexity and self-organization theories (Siemens, 2004) [12]. The principles emphasize on connections with information sources, different 
fields, and ideas. This connection can be made through social networks which are built on the premise of collaboration and sharing. They are ideal for connectivity particularly in external learning situations that are not always available, or feasible, in face-to-face classrooms (Mallon, 2013) [13]. This intangible asset produced by social relationships as a result of social networking is defined as social capital (Coleman, 1994) [14]. It has been indicated that frequent library users have a higher social capital than those who use the library less often (Johnson and Griffis, 2009) [15].

Modern libraries represent ideal environments for supporting connected learning. They are centers for knowledge creation and sharing, they support self-directed and interest-based learning, and they are inclusive public spaces that bring many different groups together. Once primarily thought of as information providers or repository managers, libraries have undergone a transformation (Braun et al., 2014 [16]; Garmer, 2014 [17]; Ito \& Martin, 2013 [18]). Connected learning is an educational framework that emphasizes learning experiences that are "socially embedded, interest driven and oriented toward educational, economic, or political opportunity" (Ito et al., 2013, p. 4) [19]. Connected learning emphasizes openly networked connections outside of traditional learning spaces. Libraries can help forge those connections through social and digital media, through peer culture and teens' social lives, and by finding new audiences and outlets for youth's creative work (Hoffman et al., 2016) [20]. Public libraries may no longer be needed to provide formal community information, but they can engage as information shepherds with local community service agencies in informal community information provision (Gorichanaz and Turner, 2017) [21]. On the other hand, School libraries are centers of innovation while librarians are ambassadors of technology, makerspaces, STEM programming, and independent research. They are connectors and collaborators, working extensively alongside teaching faculty and engaging with the outside community. The same concept has been extended to Campus.

\section{Smart Campus}

Technological advances have enhanced education to new heights, where some universities can afford to upgrade their facilities, including Smart libraries. As university libraries are repositories of research in virtually all fields and libraries are accessible for the next generation of working adults, improving libraries would greatly advance society in general (Soria, Fransen, \& Nackerud, 2013) [25]. However, education and student life goes beyond the library. Education is more than effective access to information. The connectivity of devices enabled by Internet of Things (IoT) can no doubt benefit the whole campus. Institutions that adopt digital infrastructure and provides services to its users can become a Smart Campus. These include capitalizing on IoT, RFID, GPS technology (Sari et al., 2017) [26]. In this section, we outline how several initiatives in developing a Smart Campus strengthen learning capacity, happiness, and competitiveness for universities. An overview picture is shown in Figure 1. 


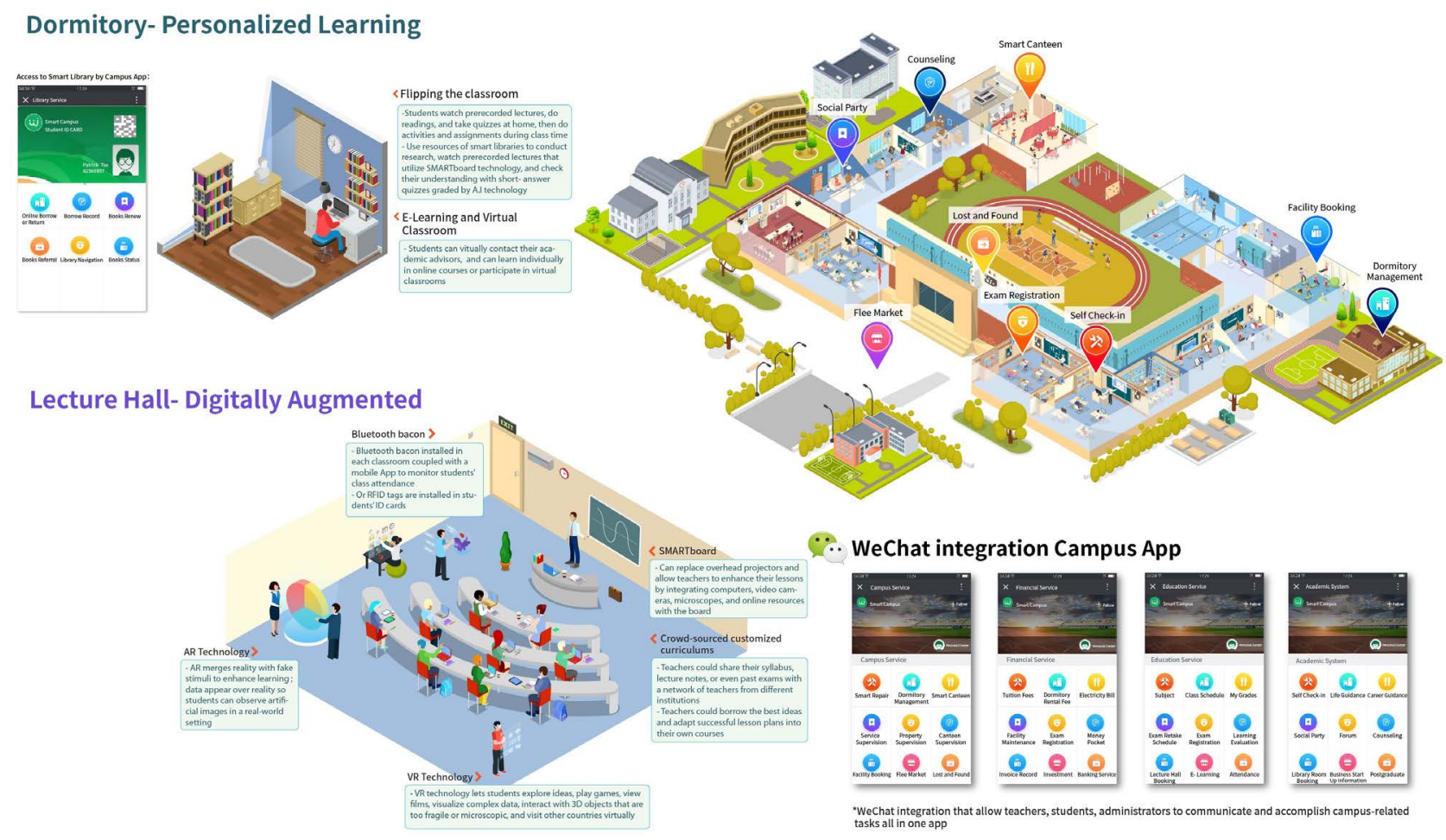

Figure 1. Smart campus.

\subsection{Digitally Augmented Learning Spaces}

Learning in universities tends to occur in classrooms or lecture halls. Generally speaking, the professor would be in front of the lecture hall and present information in front of dozens, if not hundreds, of students. The professor could use a whiteboard or PowerPoint for ease of presentation, or even use science experiments to illustrate a phenomenon. Even though professors in smaller classrooms can more easily interact with individual students or small groups of students, tools in these traditional learning spaces are limited. Relying on PowerPoint, books, iClickers, and the occasional hands-on could greatly benefit from additional technology (Mayer et al., 2009) [27]. Although this type of learning has worked in many fields that centers around texts and the exchange of ideas that can be adequately communicated via class discussions or essays (e.g. English, philosophy, communication), many fields that involve micro or macro visualization (e.g. STEM) would need digitally augmented classrooms. Universities that adopt these technologies would be more competitive as students cannot learn the same way by themselves.

On a small scale, the Internet of Things allows physical learning spaces to be digitally augmented (Price \& Rogers, 2004) [28]. Given that physical engagement increases involvement in learning, and augmented classrooms have shown to pique students' interests, this technology would enhance learning capability. Traditional lecture halls could be redesigned by arming them with SMARTboards, virtual reality headsets, or augmented reality (Wu et al., 2013) [29]. SMARTboards can replace overhead projectors and allow teachers to enhance 
their lessons by integrating computers, video cameras, microscopes, and online resources with the board. These SMARTboards can serve as digital whiteboards; teachers can project their PowerPoint slides whilst writing on them. Teachers can bring up previously saved slides via QR codes and hand out virtual copies of class notes without a printer. Students can see the board update on their screens in real-time, and even contribute to the whiteboard by drawing on their own screens. They can customize their digital class notes with their classmates' notes, animations, or links to online resources.

Besides SMARTboards, VR technology lets students explore ideas, play games, view films, visualize complex data, interact with 3D objects that are too fragile or microscopic, and visit other countries virtually (Merchant et al., 2014) [30]. Students interested in painting can use "Tiltbrush" to paint in a variety of colors, brush styles, and in a 3D setting without wasting canvases. Tiltbrush allows students to navigate around their painting, import previously drawn art into their work, and easily share their work. Medical students can use "Share care", which visualizes various human organs (e.g. brain, stomach, and kidney) at various levels of analysis. Students can rotate these organs and learn about the human body in ways that no traditional textbook can provide. Organs in Share care have labeled descriptions on them, thereby supplementing visuals with factual information. Lamb et al. (2018) [31] found that learning science concepts are using VR technology, specifically DNA, increased students learning due to the realism and 3D modeling. But it doesn't stop there. VR has been used as an effective way to simulate dangerous scenarios such as earthquake or evacuation training (Feng et al., 2018) [32]. Instead of flyers or posters on what to do during these dangerous situations, immersive VR can help humans envision the situation, which includes moving, crouching, turning, and simulate quick reactions to fake stimuli. Immersive VR can provide better memory recall ability compared to non-immersive VR conditions (Krokos, et al., 2018) [33]. Their research showed that participants felt more focused on the task due to better immersion experience.

Lastly, classrooms can be augmented with computer-generated stimuli that appear in reality, namely augmented reality. AR technology can be cost-effective; students can download apps and utilize AR through their smartphone cameras. AR merges reality with fake stimuli to enhance learning; data appear over reality so students can observe artificial images in a real-world setting. There are currently $\mathrm{AR}$ apps for almost any subject, such as geometry, translation, math, and art. For instance, users of the free Google Translate app can translate text into other languages in real-time by capturing the text on their smartphone.

Together, digitally augmented classrooms strengthen learning capacity, happiness, and competitiveness of universities. Admittedly, incorporating these technologies is costly and time intensive but the investment brings long-term benefits. Traditional classrooms can be replaced by online courses, but augmented classrooms cannot be. While augmenting digital classrooms is one way 
Smart Campus can assist education, smart campuses enhance learning in other ways as well.

\subsection{Enhancing Student Learning and Teacher's Instruction}

Learning is both the student and instructor's responsibility. Professors are responsible for delivering and facilitating content delivery and application while students are expected to engage in the material. Since many university classes are so big that taking attendance becomes a daunting task, it is unrealistic to expect professors to remember every student's face or call out each name one by one. Yet, keeping track of attendance is useful because participation is essential in some courses and attendance is a predictor for class success (Credé et al., 2010) [34]. Fortunately, teachers can accurately and efficiently monitor students' class attendance via RFID tags in student ID cards. Another option is using Bluetooth bacon installed in each classroom coupled with a mobile App since almost all students are equipped with smart phone.

Teachers can also use IoT technology to monitor students' learning in other ways, all of which could be computer-automated and presented to teacher in an efficient manner. Teachers can monitor their student's attendance in other classes to find out the student's overall engagement with academics. If a student consistently attends one class but consistently misses another, it may indicate the amount of effort and dedication the student is putting in respective classes. Teachers can use this data to track their own teaching performance, with the assumption that students who regularly attend class are expected to do better. Moreover, teachers can analyze the types of words and thoughts the students are often engaged in when posting on class discussion boards. Programs such as the Linguistic Inquiry and Word Count (LIWC) counts the number of psychologically meaningful words and groups the frequency of these words into categories. As language is a marker of cognitive processes, researchers have used LIWC to predict people's personality style, social relations, and attitudes towards various social issues (Pennebaker \& Graybeal, 2001) [35]. Another program that analyses written text is automated integrative complexity (Conway et al., 2014) [36], which tap into how complex a passage of text is. This computer program codes the structure of thoughts from 1 to 7 (with paragraphs as the typical unit of analysis), with more complex thoughts represented by higher scores. Simple thoughts represent a more unidimensional opinion of an idea, whereas more complex thoughts represent multi-faceted thoughts about an idea. Complexity of ideas has shown to predict quality of decision-making. Coding student's complexity in class discussions or even short essays can be hugely beneficial in classes that center on the exchange of ideas. Put together, analyzing students' language in numerous class discussion posts allows teachers to tap into the student's frame of mind. These programs together can monitor students' pace of learning over a given time span. A smart campus allows teachers can delve into both the content and structure of their student's thoughts. 
Internet of Things (IoT) can also help students with disabilities succeed in the classroom. Students who struggle in class due to a medical condition often request a note-taker to keep up (Boyle \& Weishaar, 2001) [37]. The note-taker is usually a fellow classmate whose notes are shared with the disabled students. However, the notes are not guaranteed to be good, people have different styles of taking notes, and notes might be too brief or too detailed for the disabled students. In addition to note-takers, disabled students could benefit from adopt automated audio transcribing technology that records and transcribes the instructor. If the teacher permits, the note-taker could use apps such as "Trint" which records and transcribes audio and video files. Classrooms could instill their own recording devices to ensure that people sitting in the back of the lecture hall can still record the lecture clearly. These transcribed files can be seamlessly edited (e.g. highlight, elaborated, trimmed) and be shared with other users. These transcribed files can supplement class notes for students and serve as a tool for teachers to keep a record of what they taught in class. Inexperienced teachers may want to recall what they said to improve how they deliver their lectures in the future.

To further improve pedagogy, different instructors teaching the same courses could pool their knowledge to create crowd-sourced customized curriculums with replicable instructions (Johnson, 2006) [38]. Teachers could share their syllabus, lecture notes, or even past exams with a network of teachers from different institutions. If done correctly, teachers could borrow the best ideas from different teachers and adapt successful lesson plans into their own courses. Extending this further, teachers could share practices of augmented classrooms and exemplary student work (with the names removed).

One example of customized curriculum is the creation of a textbook via compilation chapters. For instance, many scholars recognize that textbooks are expensive (and possibly outdated) but writing a textbook themselves is far too strenuous. One non-profit publisher called NOBA tackled this problem by getting top scholars in various areas of psychology to write one chapter of the book with respect to their expertise. NOBA then makes the book completely free to students if they access the book online. NOBA also provide instructors with a bank of exam questions, lecture notes, suggested activities, as well as premade PowerPoints with detailed notes after instructors verify their identity. This allows students to save money on an updated textbook written by experts and instructors to teach a customized curriculum, as they can choose to build their textbook by selecting which chapters to incorporate.

These initiatives strengthen learning capacity, which subsequently increases happiness as learning is made more effective and engaging. Students would potentially get more individualized attention when their written work and attendance is tracked, while teachers' pedagogy would increase.

\subsection{Developing a Campus App}

Smart Campuses not only enhance learning, but also campus life in general. For 
instance, some universities have utilized WeChat integration that allows teachers, students, administrators to communicate and accomplish campus-related tasks all in one app. These include voicing out opinions (and offering feedback) on various class and university policies, getting updates of campus facilities for effective coordination, posting and selling sell second-hand items, a virtual collective lost-and-found platform, a place for admin to release campus-wide news, and a tool for teachers to communicate with their class beyond Email. This concept has been developed into a Campus App, and other universities can follow suit. By the same token, individual institutions can fund apps that keep track of where their shuttle buses are in real time (e.g. Ride Systems which track campus shuttle buses in various U.S. universities), or available parking spots on campus.

\subsection{Cognitive Offloading}

Smartphone apps today have permitted students to look up their schedule, Emails, social media, and to access the Internet (Mims, 2012) [39]. Data stored in one's smartphone serve as a digital repository that allow users to "cognitively offload" information, thereby reducing our cognitive demands to remember our schedules, appointments, and to-do lists (Risko \& Gilbert, 2016) [40]. Because humans cannot retrieve everything in a given point in time, offloading detailed information such as scheduling frees up our mind to tackle other tasks.

Students who use campus apps such as WeChat integration allows them to cognitively offload their schedule, with all of their class times and professor's office hours already inputted. Teachers who use campus apps can look at when students have scheduled to meet with them, saving them the effort of inputting the appointment into their calendar. The app could remind both students and teachers to complete tasks via time-based or location-based pop-up messages. Nonetheless, overreliance on cognitive offloading can impair spatial memory (e.g. drive navigation if one overlies on using a GPS), episodic memory (e.g. remember specific events in one's life), and prospective memory (e.g. remembering to do things in the future) (Risko \& Gilbert, 2016) [40]. Cognitive offloading is handy, but one should be cautious of over relying on their digital repositories.

In sum, a Smart Campus has many benefits, including augmented learning spaces, student learning and teaching instruction, campus apps that contains a plethora of benefits, and cognitive offloading. These initiatives not only improve learning capability, happiness, and competitiveness, but also the advancement of education and knowledge proliferation.

\section{Smart Library}

This paper reveals the smart library in reality. The applications below are divided into three sections namely Intelligent and Organized (Table 1), Apomediated (Table 2), and Personalization (Table 3). An overview picture is depicted in Figure 2.

Intelligent \& Organized 
Table 1. Intelligent and organized. (Source: http://www.hkc.com.hk/library-management/ [40]).

\begin{tabular}{|c|c|}
\hline Product & Features \\
\hline RFID Applications & $\begin{array}{l}\text { - } \quad \text { RFID tags inside each book } \\
\text { - } \text { when patroeps passing through the gate without check-out the items } \\
\text { - } \quad \text { Counts the number of visitors to view library traffic } \\
\text { - } \quad \text { Configure settings and view statistics remotely } \\
\text { - } \quad \text { Customizable graphic panels to match the library theme and style }\end{array}$ \\
\hline Smart Bookshelf & $\begin{array}{l}\text { - } \quad \text { Returned items available immediately } \\
\text { - } \quad \text { Automatically detects on-shelve books which can help to eliminate queues with a dedicated returns area } \\
\text { - } \quad \text { Security is set and LMS is automatically updated, items are ready for circulation immediately }\end{array}$ \\
\hline $\begin{array}{c}\text { 24-hour } \\
\text { Self-Service Library }\end{array}$ & $\begin{array}{l}\text { - Extends the coverage and accessibility of the library service so that library can offer patron a self-service } \\
\text { experience of locations and times more convenient to them. } \\
\text { - } \quad \text { Automatically distributes reserved books into dedicated smart shelf holes } \\
\text { - } \quad \text { Real time tracking and monitoring } \\
\text { - } \quad \text { On shelve book browsing through touch screen monitor or apps } \\
\text { - } \quad \text { Integrated with RFID, patrons can easily return multiple items at one time } \\
\text { - } \quad \text { LMS automatically updates once item is collected or returned } \\
\text { - Monitor abnormal user behavior e.g. patron has picked up overdue items, report for missing } \\
\text { - } \quad \text { items/damaged items or hardware problems }\end{array}$ \\
\hline Smart Locker & $\begin{array}{l}\text { - Designed for RFID tagged items, providing the borrow or return items and integrated with LMS } \\
\text { - It allows using library card or ID card to login the locker, and it will show the items inside the } \\
\text { particular locker on the screen } \\
\text { - } \quad \text { Items which is remove from the locker or put into the locker will be detected and check-out/check-in to LMS } \\
\text { - } \quad \text { Patron can borrow or return items at anytime and anywhere } \\
\text { - } \quad \text { Flexible and highly customized with any dimensions to fit the location and environment } \\
\text { - } \quad \text { Patron can also use the app to reserve the item and collect them from the locker }\end{array}$ \\
\hline Robot (Stock take) & $\begin{array}{l}\text { - Automatic moving robot to facilitate navigation by building a map, set its location and } \\
\text { navigate to the target location and doing stock take } \\
\text { - Will be equipped with touch screens and voice recognition system } \\
\text { - Can support both HF or UHF RFID tag } \\
\text { - It can identify the lost books and check the wrong place-books then generate reports for } \\
\text { librarians to take further action } \\
\text { - Automatic provides stock count report }\end{array}$ \\
\hline $\begin{array}{c}\text { Book Drop } \\
\text { and Sorting Unit }\end{array}$ & 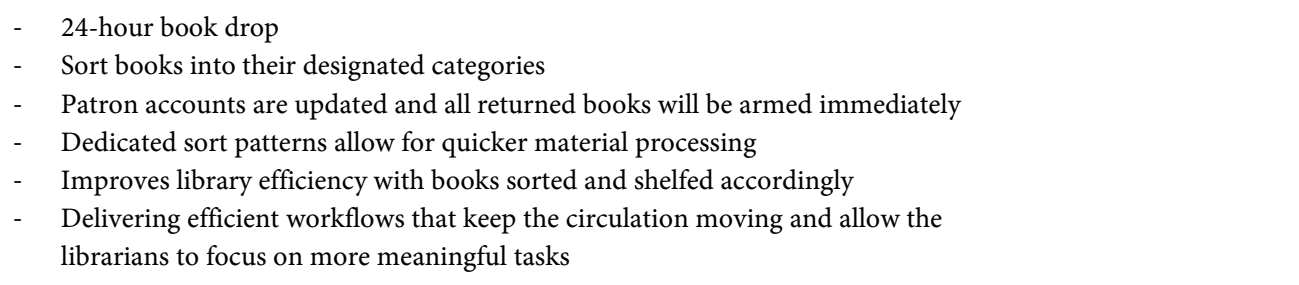 \\
\hline $\begin{array}{l}\text { Room \& Equipment } \\
\text { Booking System }\end{array}$ & $\begin{array}{l}\text { - } \quad \text { On-line booking of library facilities such as function rooms and multimedia equipment } \\
\text { - } \quad \text { Integrated with access control to authenticate users } \\
\text { - } \quad \text { Support synchronize among your phone, tablet and computer in real time } \\
\text { - } \quad \text { Pre-booking with selection of the multimedia equipment } \\
\text { - } \quad \text { Ready scene settings and door access based on booking arrangement } \\
\text { - } \quad \text { Provides comprehensive reports that shows facilities usage, income and for further analysis } \\
\text { - } \quad \text { Customization of themes and details } \\
\text { - }\end{array}$ \\
\hline
\end{tabular}




\section{Continued}

\begin{tabular}{cll}
\hline & - & Encourages self-service \\
Self Check-In/Out & - & Hybrid system (HF/UHF/EM) to allow easy deployment and upgrades \\
Station & - & Tble to collect and analyzes user behavior \\
& - & Drive attendance to programs and events which can increase the marketing efforts and drive engagement. \\
& - & Customize promotions with user-friendly templates which can make a greater impact by \\
& & scheduling promotions to target patrons \\
Book Sterilizer & - & Kills $99.7 \%-99.9 \%$ germs/virus in 30 seconds \\
& - & Kills E. Coli and Staphylococcus aureus \\
& - & Allows disinfecting up to 6 books at the same time \\
& - & Has a remaining time countdown function \\
& - & Sanitizes book cover and inside page with air blower \\
- & Safety interlock to stop the operation when door is opened \\
& - & Tempered glass at the front door to block the UV-C light \\
\hline
\end{tabular}

Table 2. Apomediated. (Source: http://www.hkc.com.hk/library-management/ [41]).

\begin{tabular}{cll}
\hline Product & & Features \\
\hline Intelligent & - & Monitors abnormal user behavior \\
Monitoring System & - & Integrated with security system to pop up problem location \\
& Authority setting for different access levels in the web interface \\
& - & Beacon for navigation \\
& $>$ Provides navigation function \\
& $>$ Offers location-based promotions/services \\
Real Time & $>$ Convenient searching \\
Location System & $>$ Leservation of library resources \\
& $>$ Event promotions \\
& $>$ Enables social interactions \\
& $>$ Integrated with recommender
\end{tabular}

Table 3. Personalization. (Source: http://www.hkc.com.hk/library-management/ [41]).

\begin{tabular}{cll}
\hline Product & & \multicolumn{1}{c}{ Features } \\
\hline \multirow{2}{*}{ Recommender } & - & Recommends books based on user preferences \\
System & - & Identifies user's previous records. Content-based or/and collaborative filtering \\
& - & The user also can view recommended item from their friends \\
Face Recognition & - & Identifies user for security or recommender \\
System & - & Report to the security room immediately once in the event of abnormal behavior \\
& & and statistical reports \\
& - & To greet patron as enter the library \\
AI Greeting & - & Autonomous navigation \\
Robot & - & Make conversation with pre-programmed scripts \\
& - & Enable to print and scan QR code \\
& - & Enable to support multi-languages \\
\hline
\end{tabular}

The library is intelligent: Self-renewing, flexible, functional, integrated, efficient, resilient, autonomous and sensitive (adaptive).

The library is organized: Turn the unorganized web of information into a systematic and useable body of knowledge by exhaustively describing and linking 


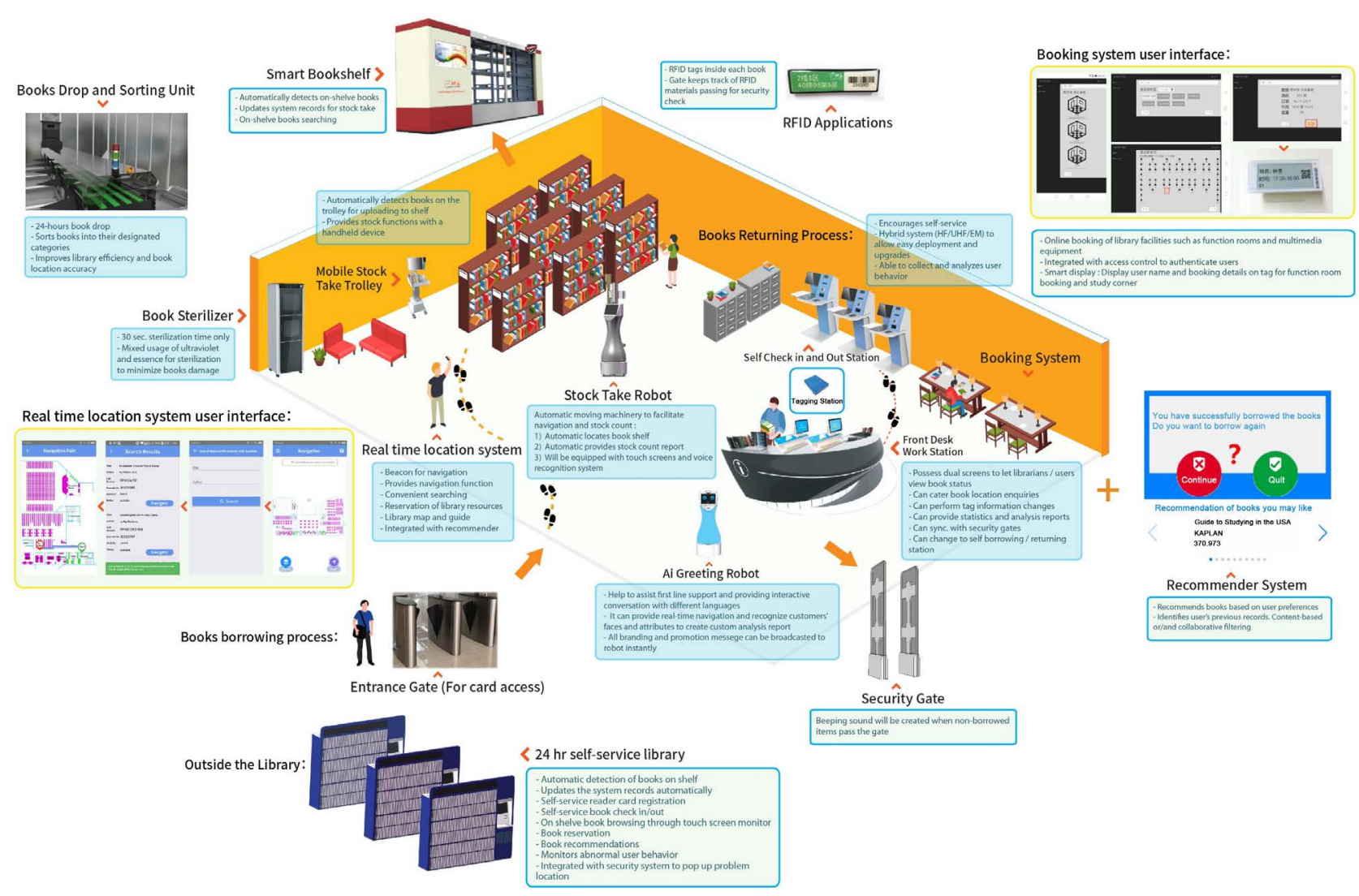

Figure 2. Smart library.

every piece of data to enable ease of access.

\section{Apomediated}

The library is apomediated: Stand by the users and guide them to high quality information and services.

\section{Personalization}

The library is personalized is similar to what various service providers such as search engines and the media were offered their clients on various Internet platforms.

\section{Impact on the Education System}

With all the benefits of smart library and smart campus, how does it translate to the current education system? Does it align with current practices or deviate far from it? Implementing smart libraries and campuses are no doubt costly, but we argue the benefits of investing in this new technology outweigh the costs; it brings massive benefits in the long term for students and society at large. Granted, adapting to this new technology calls upon intricate logistics and policies, but that has been the case for all technological advancements. Below, we outline how these new forms of education students excel in personalized learning, e-learning, virtual classroom, and digital literacy. We also outline challenges along the way. 


\subsection{Personalized Learning}

Traditional learning in the $20^{\text {th }}$ century grouped students by age cohorts instead of ability (Leland \& Kasten, 2002) [42]. Like goods in a factory, students are expected to go through the "factory of education" and come out with similar outcomes. This factory model of education assumes that age and ability are correlated, but this might not be the case. Students in this education model are homogenous, curriculum in these models tends to be standardized, and competition among cohorts is vast.

Today, many education systems have moved towards a more personalized style of learning. Students in the Advanced Placement program can choose which courses to take and which courses not to take in an order of their preference, which enables students of different ages to take the same classes. Students in the International Baccalaureate (IB) program choose which subjects to take at "higher-level", and which subjects to take at "standard-level," or choose to take some IB courses to receive a certificate instead of a diploma. In higher education, some areas of study permit the student to craft their own progress (i.e. which classes to take across multiple semesters) to complete their degree. Evidently, education today has granted some degree of flexibility than before. With smart libraries and smart campuses, students would be able to personalize their learning to new heights.

Promulgation of new technology enables educators to use the flipped classroom, which occurs when activities that are conventionally completed in the class are done at home, while activities conventionally done in the home are done in class, thereby "flipping the classroom." In these types of classrooms, students watch prerecorded lectures, do readings, and take quizzes at home, then do activities and assignments during class time (Akçayır \& Akçayır, 2018) [43]. Students can rewatch the lectures and re-take the quizzes as studying tools.

The flipped classroom could encourage students to use the resources of smart libraries to conduct research, watch prerecorded lectures that utilize SMART board technology, and check their understanding with short-answer quizzes graded by A.I. technology in their own time outside of class. Given that flipped classrooms use online materials for content delivery before class, students can learn anytime and anywhere (He, Holton, Farkas, \& Warschauer, 2016) [44]. Teachers can make use AR and VR technology for demonstrations in class and give more personalized attention to each student. The teacher in flipped classrooms assists the students and not just delivers information, while students are responsible for their own understanding.

Research on the flipped classroom has found that class time use was more efficient because class time is freed up for student-centered learning such as discussion, hands-on activities, and in-person feedback on assignments (Kunze \& Rutherford, 2018) [45]. However, the workload for both students and teachers are more intense than traditional learning. 


\subsection{E-Learning and Virtual Classroom}

Some universities today already offer online degrees (even at the post-grad level) so those who cannot afford to temporarily relocate to the university (e.g. working adults) can still obtain their degree. E-learning allows learning to occur virtually anywhere and anytime, making education free of time and geographical constraints. How can a smart campus benefit e-learning?

Students admitted to pursue education in a smart campus can learn without physically being on campus. Students can virtually contact their academic advisors, and can learn individually in online courses or participate in virtual classrooms. Student could enter a virtual classroom via their own computer anywhere in the world and see other students and the teacher virtually. In these classrooms, students and teachers can still interact by speaking, virtually raising one's hands, and have their avatar react to other people's thoughts (e.g. with a smile or confused look). Virtual classrooms have been used before. Petrakou (2010) [46] had American and Swedish students take a course in a virtual classroom with an avatar with good results. However, students in this virtual classroom who faced technical issues could not immediately notify the teacher, which goes to show that entering a virtual classroom requires getting acquainted to new norms of interaction. Technical issues aside, virtual classrooms allows people to learn together regardless of location. Students can be in the same class in a virtual setting with classmates from different countries and of different age groups. Virtual classrooms disengage from the factory model of learning and boasts personalized learning.

Of course, virtual classrooms have the drawback of requiring students from different countries to log in at a certain time, and time-zone differences can pose a problem for flexibility. Fortunately, e-learning does not necessitate use of virtual classroom and e-learning still be free from time constraints. Instead of joining virtual classrooms, students and teachers can communicate via discussion boards, Emails, and recorded messages in their own time. This type of communication learning, termed asynchronous learning, occurs because the student and teacher are not necessarily online at the same time (Vrasidas \& McIsaac, 2000 [47]; Sutton, 2001 [48]). In these cases, computer-mediated communication (CMC) in asynchronous learning environments means students and teachers to communicate at different time intervals. While this permits flexibility for both parties, real-time face-to-face discussions are often faster, easier, and convenient. While CMC gives students more time to analyze content and students can learn at their own pace. This type of communication can also be frustrating as discussion threads could take a long time. Thankfully, research on online courses found that asynchronous learning does not encourage students skipping courses, and can, in some cases, increase communication with instructors. Compared to CMC, real-time communication has the benefits of facial and auditory cues, and immediate feedback. An and Frick (2006) [49] found that students preferred CMC when it came to simple tasks, but face-to-face communica- 
tion for more complex tasks. With this in mind, e-learning might be more effective when teachers communicate with their students in more detailed ways (e.g. video-conferencing) or elaborate Emails when tasks are complex. That said, e-learning is more than communication between students and teachers.

Integration of smart library resources into online courses would enable students to conduct research online anywhere in the world using the library's resources, provided there is Internet connection. Students can have access to the campus' smart library that will find, collect, and synthesize relevant research information like a colleague. That, and uses of IOT-based programs that edits one's grammar, spelling, tone, and word choices (e.g. Grammarly) can improve student's writing proficiency. Use of the smart library can be customized such that background readings are based on their student's level, which can be assessed through a diagnostic test that captures the student's current level of education (Tang \& McCalla, 2003) [50]. Furthermore, IoT technology can link students in the same online courses together, enabling collaborative research projects and pooling of research resources.

Incorporating smart library has tremendous benefits, but its use in online learning creates implications for curriculum development. Educators need to decide the appropriate extent of using smart library, and find ways to give feedback to students on how they used the library's resources. To facilitate students' research skills, college classes that involve research papers may need to adopt guidelines to teach students how to use but not over rely on the smart library.

E-learning is not the same as traditional learning. Smart technology improves learning, but this advancement faces pushback. This new way of teaching requires people to be "technological-savvy' at a basic level, and long-time educators who taught a subject for many years may resist redesigning their courses. Additionally, integrating text, video, and animations does not always promote understanding. It is expensive to develop multimedia instructions, and research shows that rich media is effective for complex learning, but ineffective for simple learning (Sun \& Cheng, 2007) [51]. Sometimes, learning the traditional way, regardless if it is online or offline, is more effective. Lastly, e-learning in the digital age faces the issue of academic cheating.

\subsection{Issue of Academic Cheating}

In online courses, teachers communicate with students entirely online. Teachers likely never see their students via video conferencing or virtual classrooms and cannot verify whether the assignments they receive are indeed the student's work. Students who want to receive a degree without learning can pay someone else to complete the online coursework under the student's name. Cheating in tests is also much easier because students can have someone else take the test for them, or have students who already taken the same test to send them the answer. Although this can be alleviated by having teachers create different versions of the same test, this gives only puts more strain on the teacher's workload and different tests may not be equal in terms of fairness. 
Because there is no way to verify the authenticity of the student's quizzes, tests, essays, and assignments, this can inadvertently encourage cheating, fabrication, plagiarism, and collusion (Northcutt et al., 2016) [52]. Honest students may choose to cheat because they think they will be unfairly disadvantaged if they do not cheat as well (Parks et al., 2018) [53]. Honest students may also cheat if they think the education system is unfair. To make matters worse, there is a high correlation between students who cheat in academics and those who cheat in professional settings. Implications of cheating in online courses raise questions of whether students really earned the degree, and if students who obtain a degree with online courses are qualified for certain jobs.

\subsection{Digital Literacy}

In today's digital age, citizens in developed countries tend to use their digital devices in many important activities (e.g., Email, social media, banking, GPS, purchasing plane tickets, professional video-conferencing). This reliance on digital devices prompts the need for people to increase their digital literacy (EshetAlkalai, 2004) [54]. For instance, many people spend up to one-third of their time on computers devoted to email communications (Acton, 2013) [55]. Many companies market their products and maintain their brand image via social media (Laroche et al., 2013) [56]. As such, students need to have a minimum grasp of digital literacy before moving into the job market. Making use of technological advances would fulfill this goal.

Understanding the basics of today's digital world involves knowing how to search and manage online information, as well as discerning the good sources from the bad (Koltay, 2011) [57]. Even though smart libraries help students compile relevant sources, it is ultimately up to the student to critically analyze the veracity of those sources. Arming students with digital literacy will allow them to thrive in an age where virtually everything is virtual.

\section{Conclusion}

All in all, while smart library and smart campus align with the development trend of education, its adoption can strengthen the competitiveness of city since high education and training is one of the 12 pillars of Competitiveness measurements. Its effect on happiness seems to be positive but needs to be reassured through a quantitative study. Many academics have operationalized happiness in different ways, from a the social science perspective of subjective well-being (e.g. Diener, 2000 [58]; Diener, Oishi, \& Lucas, 2003 [59]; Diener, Oishi, \& Lucas, 2015 [60]; Lyubomirsky, 2013 [61]), a philosophical perspective on what makes humans happy (e.g. Haidt, 2006 [62]; Gilbert, 2007 [63]), and here we define happiness using the Happy Planet index (HPI) because it considers large-scale quantifiable and comparable measures across countries (Happy Planet Index, 2018) [24]. HPI goes beyond one's subjective assessment of happiness and instead measures happiness under the context of long-term sustainability. This 
index includes 4 components: 1) well-being (taken from Gallup World Poll's data on citizens in each country rating their satisfaction with life overall), 2) life expectancy (taken from United Nation's data on the average number of years citizens in each country is expected to live), 3) inequality of outcomes (compares the distribution life expectancy to well-being in a percentage), and 4) ecological footprint (which calculates the average person's impact on the environment). Put together, the HPI is calculated by [well-being $\mathrm{x}$ life expectancy $\mathrm{x}$ inequality of outcomes] all divided by a [standardized measure of ecological footprint]. If we apply use this conceptualization of happiness, smart campus and library might increase happiness. Technological advances will undoubtedly increase well-being because of all the benefits education and convenience it brings. Bolstering education and access to information elevates society as a whole. However, it may also increase inequality of outcomes between and within countries. Wealthy countries will be able to adopt smart campus, smart libraries, and even smart cities, while other less wealthy countries may potentially lag behind. That being said, technological advances always come with this issue of who benefits from it. Since it is virtually impossible for new technological to benefit everyone, some people will inevitably not get the benefits until later. For instance, the introduction of the Smartphone creates a barrier between the haves and have nots, but later on the smartphone market saturated in some parts of the world.

\section{Limitations and Future Research}

The automation of library has been changing with the evolution of Web4.0. It is in fact part of the Smart Campus which is still in its infant stage. How would it be integrated seamlessly with the Smart Campus worth further study. Its impact on happiness needs a longitudinal study. Another upcoming application is the Blockchain which is a decentralized secure information technology creating and maintaining a global ledger of transactions that doesn't require a third-party middleman such as a bank, government or corporation. The idea rests on four pillars, namely transcripts retrieval, transcript detail information storage, authenticity and verification of certificate, and academic records update with a common standard across institutes for ongoing education.

The adoption of any technology in education should strengthen our capability and capacity in acquiring new knowledge, and making learning more fun. Smart Campus and Smart Library should produce Smart People.

\section{Conflicts of Interest}

The authors declare no conflicts of interest regarding the publication of this paper.

\section{References}

[1] Hanekop, H. and Wittke, V. (2006) Das wissenschaftliche Journal und seine möglichen Alternativen: Veränderungen der Wissenschaftskommunikation durch das 
Internet. In: Hagenhoff, S. (Hrsg.): Internetökonomie in der Medienbranche, Universitätsverlag Göttingen.

[2] Noh, Y. (2015) Imagining Library 4.0: Creating a Model for Future Libraries. The Journal of Academic Librarianship, 41, 786-797.

https://doi.org/10.1016/j.acalib.2015.08.020

[3] Best, D. (2006) Web 2.0: Next Big Thing or Next Big Internet Bubble? Technische Universiteit Eindhoven.

[4] Habib, M.C. (2006) Toward Academic Library 2.0: Development and Application of a Library 2.0 Methodology. Unpublished Master's Dissertation, University of North Carolina at Chapel Hill.

[5] Alotaibi, S. (2010) Semantic web Technologies for Digital Libraries: From Libraries to Social Semantic Digital Libraries (SSDL). Over Semantic Digital Libraries (SDL). The 4th Saudi International Conference, University of Manchester, UK.

[6] Patel, K. (2013) Incremental Journey for World Wide Web: Introduced with Web1.0 to Recent Web 5.0-A Survey Paper. International Journal of Advanced Research in Computer Science and Software Engineering, 3, 410-417.

[7] Gundala, S. (2016) Education Systems around the World: A Comparison. https://www.linkedin.com/pulse/education-systems-around-world-comparison-sas $\underline{\text { hi-gundala/ }}$

[8] Cann, O. (2017) What Exactly Is Economic Competitiveness? https://www.weforum.org/agenda/2017/09/what-is-economic-competitiveness

[9] The Worldwide Educating for the Future Index (2018). https://yidanprize.org/research/

[10] World Economic Forum (2017) White Paper, Realizing Human Potential in the Fourth Industrial Revolution. http://www3.weforum.org/docs/WEF_EGW_Whitepaper.pdf

[11] World Economic Forum, Mapping Global Transformations. https://toplink.weforum.org/knowledge/insight/a1Gb0000000LPFfEAO/explore/su mmary

[12] Siemens, G. (2004) Connectivism: A Learning Theory for the Digital Age. International Journal of Instructional Technology \& Distance Learning, 2.

[13] Mallon, M.N. (2013) Extending the Learning Process: Using the theory of Connectivism to Inspire Student Collaboration. Kansas Library Association College and University Libraries Section Proceedings, 3.

[14] Coleman, J.S. (1994) Foundations of Social Theory. Harvard University Press.

[15] Johnson, C.A. and Griffis, M.R. (2009) A Place Where Everybody Knows Your Name? Investigating Relationship between Public Libraries and Social Capital. Canadian Journal of Information and Library Science, 33, 159-191.

[16] Braun, L.W., Hartman, M.L., Hughes Hassell, S., Kumasi, K. and Yoke, B. (2014) The Future of Library Services for and with Teens: A Call to Action. YALSA, Chicago.

[17] Garmer, A.K. (2014) Rising to the Challenge: Re-Envisioning Public Libraries. The Aspen Institute, Washington DC.

[18] Ito, M. and Martin, C. (2013) Connected Learning and the Future of Libraries. Young Adult Library Services, 12, 29-32.

[19] Ito, M., Gutiérrez, K., Livingstone, S., Penuel, B., Rhodes, J., Salen, K., Watkins, S.C., et al. (2013) Connected Learning: An Agenda for Research and Design. Digital 
Media and Learning Research Hub., Irvine.

[20] Hoffman, K.M., Subramaniam, M., Kawas, S., Scaff, L. and Davis, K. (2016) Connected Libraries: Surveying the Current Landscape and Charting a Path to the Future. The Connected Lib Project, College Park, Seattle.

[21] Gorichanaz, T. and Turner, D. (2017) All the Community's a Stage: The Public Library's Part in Community Information Provision. The Library Quarterly, 87, 99-116. https://doi.org/10.1086/690737

[22] Chan, K. (2017) Which Countries Provide Their Citizens with the Best Higher Education?

https://www.weforum.org/agenda/2017/05/which-countries-provide-their-citizenswith-the-best-higher-education

[23] Schwab, K. (2017) The Global Competitiveness Report 2017-2018. http://www3.weforum.org/docs/GCR2017-2018/05FullReport/TheGlobalCompetiti venessReport2017\%E2\%80\%932018.pdf

[24] Happy Planet Index (2018). http://happyplanetindex.org/

[25] Soria, K.M., Fransen, J. and Nackerud, S. (2013) Library Use and Undergraduate Student Outcomes: New Evidence for Students' Retention and Academic Success. Libraries and the Academy, 13, 147-164. https://doi.org/10.1353/pla.2013.0010

[26] Sari, M.W., Ciptadi, P.W. and Hardyanto, R.H. (2017) Study of Smart Campus Development Using Internet of Things Technology. IOP Conference Series: Materials Science and Engineering, 190, Article ID: 012032. https://doi.org/10.1088/1757-899X/190/1/012032

[27] Mayer, R.E., Stull, A., Deleeuw, K., Almeroth, K., Bimber, B., Chun, D. and Zhang, H. (2009) Clickers in College Classrooms: Fostering Learning with Questioning Methods in Large Lecture Classes. Contemporary Educational Psychology, 34, 51-57. https://doi.org/10.1016/j.cedpsych.2008.04.002

[28] Price, S. and Rogers, Y. (2004) Let's Get Physical: The Learning Benefits of Interacting in Digitally Augmented Physical Spaces. Computers \& Education, 43, 137-151. https://doi.org/10.1016/j.compedu.2003.12.009

[29] Wu, H., Lee, S.W., Chang, H. and Liang, J. (2013) Current Status, Opportunities and Challenges of Augmented Reality in Education. Computers \& Education, 62, 41-49. https://doi.org/10.1016/j.compedu.2012.10.024

[30] Merchant, Z., Goetz, E.T., Cifuentes, L., Keeney-Kennicutt, W. and Davis, T.J. (2014) Effectiveness of Virtual Reality-Based Instruction on Students Learning Outcomes in K-12 and Higher Education: A Meta-Analysis. Computers \& Education, 70, 29-40. https://doi.org/10.1016/j.compedu.2013.07.033

[31] Lamb, R., Antonenko, P., Etopio, E. and Seccia, A. (2018) Comparison of Virtual Reality and Hands on Activities in Science Education via Functional near Infrared Spectroscopy. Computers \& Education, 124, 14-26. https://doi.org/10.1016/j.compedu.2018.05.014

[32] Feng, Z., González, V.A., Amor, R., Lovreglio, R. and Cabrera-Guerrero, G. (2018) Immersive Virtual Reality Serious Games for Evacuation Training and Research: A Systematic Literature Review. Computers \& Education, 127, 252-266. https://doi.org/10.1016/j.compedu.2018.09.002

[33] Krokos, E., Plaisant, C. and Varshney, A. (2018) Virtual Memory Palaces: Immersion Aids Recall. Virtual Reality.

[34] Credé, M., Roch, S.G. and Kieszczynka, U.M. (2010) Class Attendance in College. Review of Educational Research, 80, 272-295. 
https://doi.org/10.3102/0034654310362998

[35] Pennebaker, J.W. and Graybeal, A. (2001) Patterns of Natural Language Use: Disclosure, Personality, and Social Integration. Current Directions in Psychological Science, 10, 90-93. https://doi.org/10.1111/1467-8721.00123

[36] Conway, L.G. III, Conway, K.R., Gornick, L.J. and Houck, S.C. (2014) Automated Integrative Complexity. Political Psychology, 35, 603-624. https://doi.org/10.1111/pops.12021

[37] Boyle, J.R. and Weishaar, M. (2001) The Effects of Strategic Note Taking on the Recall and Comprehension of Lecture Information for High School Students with Learning Disabilities. Learning Disabilities Research and Practice, 16, 133-141. https://doi.org/10.1111/0938-8982.00014

[38] Johnson, J.A. (2006) Beyond the Learning Paradigm: Customizing Learning in American Higher Education: 10 Bellweather Principles for Transforming American Higher Education. Community College Journal of Research and Practice, 30, 97-116. https://doi.org/10.1080/10668920500432951

[39] Mims, C. (2012) A Surprisingly Long List of Everything Smartphones Replaced. https://www.technologyreview.com/s/428579/a-surprisingly-long-list-of-everything -smartphones-replaced/

[40] Risko, E.F. and Gilbert, S.J. (2016) Cognitive Offloading. Trends in Cognitive Sciences, 20, 676-688. https://doi.org/10.1016/j.tics.2016.07.002

[41] Library Management (2018). http://www.hkc.com.hk/library-management/

[42] Leland, C.H. and Kasten, W.C. (2002) Literacy Education for the 21st Century: It's Time to Close the Factory. Reading \& Writing Quarterly, 18, 5-15. https://doi.org/10.1080/105735602753386315

[43] Akçayır, G. and Akçayır, M. (2018) The Flipped Classroom: A Review of Its Advantages and Challenges. Computers \& Education, 126, 334-345. https://doi.org/10.1016/j.compedu.2018.07.021

[44] He, W., Holton, A., Farkas, G. and Warschauer, M. (2016) The Effects of Flipped Instruction on Out-of-Class Study Time, Exam Performance, and Student Perceptions. Learning and Instruction, 45, 61-71. https://doi.org/10.1016/j.learninstruc.2016.07.001

[45] Kunze, A. and Rutherford, T. (2018) Blood from a Stone: Where Teachers Report Finding Time for Computer-Based Instruction. Computers \& Education, 127, 165-177. https://doi.org/10.1016/j.compedu.2018.08.022

[46] Petrakou, A. (2010) Interacting through Avatars: Virtual Worlds as a Context for Online Education. Computers \& Education, 54, 1020-1027. https://doi.org/10.1016/j.compedu.2009.10.007

[47] Vrasidas, C. and McIsaac, M.S. (2000) Principles of Pedagogy and Evaluation for Web-Based Learning. Educational Media International, 37, 105-111. https://doi.org/10.1080/095239800410405

[48] Sutton, L.A. (2001) The Principle of Vicarious Interaction in Computer-Mediated Communications. International Journal of Educational Telecommunications, 7, 223-242.

[49] An, Y. and Frick, T. (2006) Student Perceptions of Asynchronous Computer-Mediated Communication in Face-to-Face Courses. Journal of Computer-Mediated Communication, 11, 485-499. https://doi.org/10.1111/j.1083-6101.2006.00023.x

[50] Tang, T. and Mccalla, G. (2004) Evaluating a Smart Recommender for an Evolving 
e-Learning System: A Simulation-Based Study. Conference of the Canadian Society for Computational Studies of Intelligence, London, 17-19 May 2004, 439-443. https://doi.org/10.1007/978-3-540-24840-8_34

[51] Sun, P. and Cheng, H.K. (2007) The Design of Instructional Multimedia in e-Learning: A Media Richness Theory-Based Approach. Computers \& Education, 49, 662-676. https://doi.org/10.1016/j.compedu.2005.11.016

[52] Northcutt, C.G., Ho, A.D. and Chuang, I.L. (2016) Detecting and Preventing "Multiple-Account" Cheating in Massive Open Online Courses. Computers \& Education, 100, 71-80. https://doi.org/10.1016/j.compedu.2016.04.008

[53] Parks, R.F., Lowry, P.B., Wigand, R.T., Agarwal, N. and Williams, T.L. (2018) Why Students Engage in Cyber-Cheating through a Collective Movement: A Case of Deviance and Collusion. Computers \& Education, 125, 308-326.

https://doi.org/10.1016/j.compedu.2018.04.003

[54] Eshet-Alkalai, Y. (2004) Digital Literacy: A Conceptual Framework for Survival Skills in the Digital Era. Journal of Educational Multimedia and Hypermedia, 13, 93-106.

[55] Acton, A. (2017) How to Stop Wasting 2.5 Hours on Email Every Day. https://www.forbes.com/sites/annabelacton/2017/07/13/innovators-challenge-how-t o-stop-wasting-time-on-emails/\#47004153978

[56] Laroche, M., Habibi, M.R. and Richard, M. (2013) To Be or Not to Be in Social Media: How Brand Loyalty Is Affected by Social Media? International Journal of Information Management, 33, 76-82. https://doi.org/10.1016/j.ijinfomgt.2012.07.003

[57] Koltay, T. (2011) The Media and the Literacies: Media Literacy, Information Literacy, Digital Literacy. Media, Culture \& Society, 33, 211-221. https://doi.org/10.1177/0163443710393382

[58] Diener, E. (2000) Subjective Well-Being: The Science of Happiness and a Proposal for a National Index. American Psychologist, 55, 45-43. https://doi.org/10.1037/0003-066X.55.1.34

[59] Diener, E., Oishi, S. and Lucas, R.E. (2003) Personality, Culture, and Subjective Well-Being: Emotional and Cognitive Evaluations of Life. Annual Review of Psychology, 54, 403-425. https://doi.org/10.1146/annurev.psych.54.101601.145056

[60] Diener, E., Oishi, S. and Lucas, R.E. (2015) National Accounts of Subjective Well-Being. American Psychologist, 70, 234-242. https://doi.org/10.1037/a0038899

[61] Lyubomirsky, S. (2013) The Myths of Happiness: What Should Make You Happy, But Doesn't, What Shouldn't Make You Happy, But Does. Penguin, New York.

[62] Haidt, J. (2006) The Happiness Hypothesis: Finding Modern Truth in Ancient Wisdom. Basic Books, New York.

[63] Gilbert, D.T. (2007) Stumbling on Happiness. Vintage Books, New York. 